Article

\title{
Are Urban Planning Schools in the Global South Prepared for Current Challenges of Climate Change and Disaster Risks?
}

\author{
Wolfgang Scholz*(D), Tim Stober and Hannah Sassen \\ Faculty of Spatial Planning, TU Dortmund University, IRPUD, 44221 Dortmund, Germany; \\ tim.stober@tu-dortmund.de (T.S.); hannah.sassen@tu-dortmund.de (H.S.) \\ * Correspondence: wolfgang.scholz@tu-dortmund.de
}

Citation: Scholz, W.; Stober, T.;

Sassen, H. Are Urban Planning

Schools in the Global South Prepared for Current Challenges of Climate

Change and Disaster Risks?.

Sustainability 2021, 13, 1064.

https: / doi.org/10.3390/su13031064

Academic Editor: Richard

A. Niesenbaum

Received: 15 December 2020

Accepted: 18 January 2021

Published: 20 January 2021

Publisher's Note: MDPI stays neutral with regard to jurisdictional claims in published maps and institutional affiliations.

Copyright: (c) 2021 by the authors. Licensee MDPI, Basel, Switzerland. This article is an open access article distributed under the terms and conditions of the Creative Commons Attribution (CC BY) license (https:// creativecommons.org/licenses/by/ $4.0 /)$.

\begin{abstract}
This article undertakes an analysis of current urban planning programs at universities with a focus on sub-Saharan English-speaking African (SSA) and South East Asian countries (SEA) as comparison cases. The aim is to identify, as an important part of sustainability, the existence and share of climate change and disaster related courses in the curricula, and to understand to what extent these topics are already integrated into current urban planning programs at the university level and thus shape the knowledge and skills of future urban planners. The local academic and professional environments in which the programs are based are taken into account by a review of the historical development of the programs. The analysis in mid-2020 took only those universities and programs into account that have curricula and course titles available online. The data were analyzed both quantitatively and qualitatively. The second part of the research deals with the discussion of how these courses can be best integrated into the existing curricula and thus serve the adequate education of urban planners by providing some concrete ideas.
\end{abstract}

Keywords: higher urban planning education; curricula development; climate change; disaster risks; Sub-Saharan Africa; South East Asia

\section{Introduction}

This article focusses on sustainable urban development with an emphasis on climate change and disaster risks. Urban planning can have a huge impact on the sustainability of urban development due to the legal power on land-use control and the direct impact on the sustainability of the urban environment. Urban planners are thus responsible for shaping the built environment and are in charge to create solutions to the global climate change challenge. [1] (p. 1045). One prerequisite for climate change mitigation and adaptation as well as for the reduction in disaster risks is to have well-trained urban planners in these fields. Therefore, this article analyzes the urban planning programs at universities where the education of future urban planners takes place and will investigate whether the current programs are designed to equip them with the necessary knowledge on climate change and disaster risks. "Whilst there have been several studies on climate change and education, and urban planning and climate change, there are relatively few that analyze the interface between climate change, education and urban planning" [1] (p. 1047).

In the self-perception of urban planners, both in academia and as practitioners, it is common to say that "Urban planners play a significant role in shaping the development of urban areas [... ] to withstand the impacts of climate change" [1] (p. 1046).

Faling [2] (p. 1) sees "planners [ . . ] in an ideal position to contribute to the fight against climate change [ ... ]." Thus, it is worth looking into the extent to which urban planners are actually prepared to play that role. The aim is to identify the existence and share of climate change and disaster-related courses in the curricula.

The relevance of climate change and disaster preparedness in higher academic education has already been underlined in recent policy documents. Goal 13 of the Sustainable 
Development Goals (SDGs), Target 13.3, states that, to "improve education, awarenessraising and human and institutional capacity on climate change mitigation, adaptation, impact reduction and early warning" [3] (p. 27), and Article 12 of the Paris Agreement asks for "enhancing climate change education" [4] (p. 16). However, a recent worldwide survey on climate change at universities (among 1250 students from 166 universities) revealed that $43 \%$ of the students state that climate change is not sufficiently covered in their programs [1] (p. 1046).

The 2014 IPCC Report [5] underlines the role of urban planning for climate resilient urban areas to respond to climate risks. Although there is a substantial number of reports, research, and theoretical literature on how to integrate climate change mitigation and adaption into urban planning practice, some scholars, however, still see planning practitioners as not fully prepared to address the topics of climate change and risks [5-7]. Some authors identified the current urban planning curricula at the university level as a reason for inadequate climate change education $[2,8,9]$.

The two regions of sub-Saharan English-speaking Africa (SSA) and South East Asian countries (SEA) were selected due to their high risks related to climate change impacts and the relatively low coping capacity (of the public sector) to address those risks including the higher vulnerability informal settlers [10-15].

Climate change cannot be separated from other related topics for urban planners and, thus, this study also considers courses in Disaster Management, Resilient Urban Development, Environmental Hazards and Risk Management.

The second part of this study deals with the discussion on how these already offered, or still to be added, courses can be best integrated into the existing curricula and thus serve the adequate education of urban planners.

\section{Current Situation of Planning Curricula in Sub-Saharan Africa and South East Asia}

\subsection{Urban Development Trends and Curricula Development}

In the literature, there seems to be a gap identified between the theoretical knowledge available on how planning should be taught and on how it is taught currently at the university level in planning programs and thus how the curricula should look like. Let us focus first on the perception of local experts from SSA and SEA planners and planning schools on their curricula implementation [16-20].

There is a lot of literature on the planning process, but "very few [ ... ] on what kind of education and training potential planners have to acquire" [16] (p. 29). Referring to [17], Faling states the need for the revision of planning curricula: "Curricula in planning schools lag behind in promoting the fundamental transition of cities necessary to mitigate and adapt to climate change. It is therefore essential to revise the curriculum of planning degrees" [18] (pp. 254-255).

These statements can be applied, to a certain extent, to all planning programs worldwide but especially to SSA and SEA. The Association of African Planning Schools (AAPS) did already a great job by bringing African planning schools together to analyze and discuss the content and the future of planning education taking a Southern perspective as well. For more information, please consult https:/ /www.africanplanningschools.org.za/.

In order to understand the current urban planning curricula, potential shortcomings and to sensitively prepare adaptations, it makes sense to analyze their historical development first. For the case of Zambia, Phiri states that "Planning education has typically followed the British tradition of planning [ ... ]. As a result of this "Western bias", planning education has [ ... ] neither adequately reflected the cultural values, norms, traditions, and aspirations nor the socio-economic, political, and environmental concerns of Zambians" [18] (p. 1). Thus, Phiri sees an inappropriate impact on the urban planning system and its urban planning education during colonial times, which still has its consequences until today. The "Western" or better Northern influence, according to Phiri [18], does not consider local conditions adequately. 
A similar view applies to Tanzania with a focus on the "copy-and-paste" design of the planning legislation and the planning education: "The original course curriculum was based on a conception of planning [ ... ] not very different from [ . . ] England during the 1940s" [21] cited in [22] (p. 7). The same potential obstacles have to be considered when integrating new subjects, such as climate change and resilient urban development, into local planning curricula in the Global South, since the processes might repeat themselves.

In the same line argues Home [23] for Anglophone Africa, Njoh [24] for French colonial Africa and Scholz et al. [25] for the impact of colonial legislation on current planning practices and education in Ghana, Tanzania, and South Africa. Odendaal [26] sees the gap between planning legislation and education rooted in colonial times and today's reality: "Many of these ideas and practices are inappropriate in contexts characterized by rapid growth, poverty and informality" [26] (p. 174). She highlights a problem that can also apply to policy transfers in climate change and thus can be a potential obstacle for curricula development at higher educational urban planning schools in the Global South.

The emphasis on many planning curricula in the Global South is on the Northern urban model of an orderly developed town and a separation of land uses along with defined categories. Today's formal planning legislation in African countries is still deeply rooted in colonial planning ideals for the safety, sanitation, and segregation of land uses [25].

This applies similarly to the never colonized Thailand and to the impact of the US legislation in The Philippines. For Indonesia, we can trace back in detail the international influence on planning education starting after WWII [27,28]. All share, to a certain extent, the urban model of an orderly developed city, which is not fully prepared to deal with informality. Similar problems occur in countries such as Vietnam with an incomplete transition process from a top-down state-led economy and master planning approach to a more decentralized strategic planning $[13-15,29,30]$.

Since the main goal of planning education in all analyzed countries and beyond is to train practitioners for the public formal planning institutions; urban planning education also follows their codified urban planning model. Developing a Southern perspective of urban planning, urban planning approaches, and urban planning education reflecting the urban reality on the ground is thus still in progress (see also [31]).

\subsection{Recent Challenges in Planning Curricula}

Many urban planning curricula follow the idea of planning studios at different scales and focus on a disciplinary approach of various (technical) subjects, which applies also to most planning schools elsewhere (with exception of those who understand planning as a process rather than as a technical and design-oriented discipline). However, today the required knowledge is wider, more interdisciplinary, and closely linked to science [32]

Though not only additional knowledge from disciplines beyond urban design, planning law and technical aspects is needed, planning approaches are also changing to follow new methods which were mostly introduced from outside the analyzed countries. Examples would be comprehensive planning, action planning approach, structure planning, strategic planning, community or public participation, sustainable Cities Program (SCP), City Development Strategy (CDS), the Infrastructure-Led Development approach, etc., to name only a few. This means that planning programs today are already under the pressure of integrating more subjects but also must address ever-changing planning approaches. This obviously makes stable curricula development difficult, considering the long procedures inside universities and for the accreditation of program changes [19].

Additionally, there has been another long unsolved challenge: urban planning programs educate mainly planners for the public sector to follow formal planning regulations and thus face problems to address cross-cutting challenges of informal urban development and poverty. These two issues, obviously, cannot be addressed by urban planners and urban planning approaches alone. Nnkya and Lupala observe "Informal urbanization and urban poverty are the key challenges" of urban development and "initiatives towards planning and regulating informality in these cities seem to be inadequate to cope with the 
pace of development" [22] (p. 20). They thus ask correctly "How to cope with informality [... ] is perhaps the most critical question planning education should aim to address in the 21st century" [22] (p. 20)

Odendaal [26] (p. 178) highlights the ignorance of informality as an urban reality in planning education: "There is generally a disjuncture between how informality is understood and conceptualized as a feature of African urbanization and how it is addressed in curricula."

Summarizing up to here, planning education in the Global South, as in SSA and SEA, already faces challenges with the integration of new subjects, frequently changing planning approaches, and the open questions of how to deal with informality in a system of rather formal-led land use plans, and how to address (urban) poverty in planning. Therefore, the analysis of the urban planning programs in this article will not only look for climate change-related subjects but also for the abovementioned topics to gain the full picture.

\subsection{Climate Change as a Challenge for Higher Urban Planning Education}

There is a high demand by international organizations and the scientific community to integrate and mainstream climate change and disaster management in urban planning education. The Asian Development Bank [29] (p. 118) sees for SEA that monitoring climate change has been recognized but long-term planning is still inadequate. However, these topics cannot be seen separate from other current problems. Odendaal [26] sees, therefore, a strong link between climate change, disasters, and poverty: "The goal of sustainable urban development is therefore curtailed by planning systems that frustrate the efforts of the urban poor. [ ... ] There is a need to address pertinent pressures such as climate change, poverty and informality." [26] (p. 176)

Additionally, Faling [2] sees three topics under-represented in urban planning education: informality, the collaboration with stakeholder, and the linkages between urban planning and infrastructure development. For SEA countries, the Asian Development Bank [29] (p. 94) asks for "mainstreaming climate change adaptation into development planning $[\ldots]$ as an integral part of sustainable development and poverty reduction strategies" and a "multi-sector approaches to climate change adaptation, including linking climate change adaptation with disaster risk management".

The question here is, how can urban planning programs deal with new cross-cutting topics when they still struggle with the incomplete integration of the other two important cross-cutting topics of informality and poverty? How can climate change be mainstreamed into planning curricula when limited work has been done "on the impact of global warming on African cities and what that implies for the training of planners?" [26] (p. 179). The Asian Development Bank [29] (p. 92) adds the economic perspective: "Planning for coping with [ ... ] impacts of climate change requires decisions based on sound economic considerations."

Another challenge that will be discussed in the last section of the article, along with Hurlimann [20], is the question whether climate change should be integrated into the existing curriculum and courses, or taught as a separate subject? This paper asks for the integration and mainstreaming of cross-cutting topics, such as climate change impacts, resilient urban development, and disaster risk management into the urban planning curricula and to better address at the same time the prevailing conditions of poverty and informality. However, urban planning curricula cannot be overloaded simply by adding new subjects repeatedly, since most universities still struggle to integrate the topics of informality and poverty into urban planning education.

\section{Materials and Methods: Analysis of Curricula in SSA and SEA}

The article provides an overview of the subjects taught in the current urban planning programs at university level in English-speaking SSA and selected countries in SEA with a focus on classes on climate change related subjects. However, as shown before, climate change cannot be separated from other related topics for urban planners [2] (p. 11) and 
thus this study also takes courses in Disaster Management, Resilient Urban Development, Environmental Hazards and Risk Management into account. The same applies to other cross-cutting topics, such as informality, poverty, and gender.

For this article, 29 universities in nine SSA countries were analyzed (Botswana, Ghana, Kenya, Namibia, Nigeria, South Africa, Tanzania, Uganda, and Zambia) and three South East Asian countries (Indonesia, Thailand, and the Philippines) with a total of 53 urban planning programs (39 in SSA plus 14 in SEA), both at bachelor and master level (Table 1). The analysis in mid-2020 took only those universities and programs into account with online available curricula and course titles. Thus, it cannot cover all programs available in the regions.

Table 1. Analyzed planning programs in sub-Saharan Africa and South East Asia.

\begin{tabular}{|c|c|c|}
\hline Botswana & University of Botswana & $\begin{array}{l}\text { BA in Urban and Regional Planning, } \\
\text { MA in Urban \& Regional Planning }\end{array}$ \\
\hline Ghana & $\begin{array}{c}\text { Kwame Nkrumah University of Science and } \\
\text { Technology }\end{array}$ & $\begin{array}{c}\text { BA Development Planning, } \\
\text { MA Development Planning \& Management, } \\
\text { MA Development Policy and Planning, } \\
\text { MA Planning }\end{array}$ \\
\hline \multirow[t]{3}{*}{ Kenya } & Maseno University & $\begin{array}{l}\text { BA Urban and Regional Planning with IT, } \\
\text { MA Project Planning and Management }\end{array}$ \\
\hline & Kenyatta University & $\begin{array}{c}\text { BA Environmental Planning and Management, Disaster Management MA } \\
\text { Environmental Planning and Management, } \\
\text { Planning for Disaster Preparedness and Management }\end{array}$ \\
\hline & Technical University of Kenya & BA Environment in Urban and Regional Planning \\
\hline Namibia & Namibia University of Science and Technology & $\begin{array}{l}\text { BA of Town and Regional Planning, } \\
\text { BA of Regional and Rural Development, } \\
\text { MA of urban Design }\end{array}$ \\
\hline \multirow[t]{3}{*}{ Nigeria } & Obafemi Awolowo University & B. Sc. Urban and Regional Planning \\
\hline & The Federal University of Technology, Akure & B. Tech. In Urban and Regional Planning \\
\hline & University of Nigeria, Enugu & MA of Urban and Regional Planning \\
\hline \multirow[t]{7}{*}{ South Africa } & University of the Witwatersrand & $\begin{array}{l}\text { B. Sc. (Honours) Urban and regional Planning, } \\
\text { MA Urban Design }\end{array}$ \\
\hline & Durban University of Technology & BA of Built Environment in Urban and Regional Planning \\
\hline & University of Cape Town & $\begin{array}{l}\text { BA (Honours) of City Planning, } \\
\text { MA of Urban Design }\end{array}$ \\
\hline & University of Pretoria & BA of Town and Regional Planning \\
\hline & North-West University & BA of Urban and Regional Planning \\
\hline & University of Johannesburg & $\begin{array}{c}\text { BA of Urban and Regional Planning, } \\
\text { MA in Sustainable Urban Planning and Development }\end{array}$ \\
\hline & University of the Free State & MA of Urban and Regional Planning \\
\hline Tanzania & Ardhi University & $\begin{array}{c}\text { BSc in Urban and Regional Planning, } \\
\text { BSc in Housing and Infrastructure Planning, } \\
\text { BSc in Regional Development Planning, } \\
\text { PGD in Urban Planning and management, } \\
\text { MSc in Urban Planning and Management, } \\
\text { MSc in Urban and Regional Development Planning and Management, } \\
\text { Master of Disaster Risk management, } \\
\text { MSc in Disaster Risk Management, } \\
\text { MSc in Disaster Risk Management and Engineering, } \\
\text { Master of Disaster Risk management, } \\
\text { MSc in Disaster Risk Management, } \\
\text { MSc in Disaster Risk Management and Engineering }\end{array}$ \\
\hline
\end{tabular}


Table 1. Cont.

\begin{tabular}{|c|c|c|}
\hline Uganda & Makere University & $\begin{array}{l}\text { BA of urban Planning, } \\
\text { MA in Urban Planning and Design }\end{array}$ \\
\hline Zambia & Copperbelt University & BA Urban and Regional Planning \\
\hline \multirow[t]{4}{*}{ Indonesia } & Institute of Technology Bandung & Undergraduate Program Urban and Regional Planning \\
\hline & Sepuluh Nopember of Technology (ITS) & Bachelor Urban and Regional Planning Program \\
\hline & Gadjah Mada University & Bachelor in Urban and Regional Planning \\
\hline & Institut Teknologi National, Bandung & $\begin{array}{l}\text { Undergraduate: Urban and Regional Planning, } \\
\text { Master: Urban and Regional Planning }\end{array}$ \\
\hline \multirow[t]{2}{*}{ Thailand } & Thammasat University & Master of Urban Environmental Planning and Development Program \\
\hline & Asian Institute of Technology & $\begin{array}{c}\text { Master in Urban Environmental Management, } \\
\text { Diploma in Regional and Rural Development Planning, } \\
\text { Master of Urban Sustainability Planning and Design, } \\
\text { Master in Disaster Preparedness, } \\
\text { Mitigation and Management, } \\
\text { Master in Climate Change and Sustainable Development, } \\
\text { Environment and Sustainable Development }\end{array}$ \\
\hline Philippines & University of the Philippines & $\begin{array}{l}\text { Diploma in Urban and Regional Planning, } \\
\text { Master in Urban and Regional Planning }\end{array}$ \\
\hline
\end{tabular}

The online research identified, by title, a total of 831 courses for SSA and 365 courses for SEA. These courses were clustered in five constitutive steps: first, they were clustered in the main categories by the keywords in the course title (e.g., economics, design, infrastructure). Subcategories-for example, transport or water supply-were grouped in the main category of infrastructure. In a second step, the remaining courses, which could not be clustered directly by name, have been analyzed deeper in the course description, in the context of the program and finally grouped into existing categories. As a third step, the clusters were analyzed if they contained potential subcategories that justified a new category due to their importance or uniqueness, e.g., ethics in planning or private economy. As the fourth step, courses which still do not fit into one of the categories and/or appear only once were transferred to the new category "miscellaneous". These are courses with a lower relevance for this study, e.g., math or language courses. In a fifth step, all courses dealing with disaster management, risks, and climate change-related content were grouped into a new category as well as courses dealing with cross-cutting topics. The process of clustering resulted in the following categories, both for SSA and SEA: economics, private sector economics, regional planning and regional science, land management, planning law and legislation, planning policies, computer design and Computer Aided Design (CAD), computer analysis and GIS, planning fundamentals, planning theory and history of planning, planning methods, sociology, environmental planning, sectoral planning and infrastructure, urban planning and urban design, and miscellaneous. These categories help to achieve an overview on the program structures with special attention to the two categories of disaster management, risks and climate change, and cross-cutting courses, such as gender, poverty, and informality. The clustering and the order of the categories in the following figures do not indicate any hierarchy of the courses but are rather an outcome of the clustering process described above.

\section{Findings from Course Analysis}

The course analysis revealed a dominance of classical subjects in urban planning and urban design, as well as in sectoral planning and planning methods. In the following section, there is a detailed analysis of the offered courses by groups, a first interpretation of the numbers (Figure 1 for SSA and Figure 2 for SEA), and a cross-continental comparison (Figure 3). The percentages in Figure 3 are related to the continents separately to balance the different number of analyzed programs ( $n=831$ for SSA and $n=365$ for SEA). 


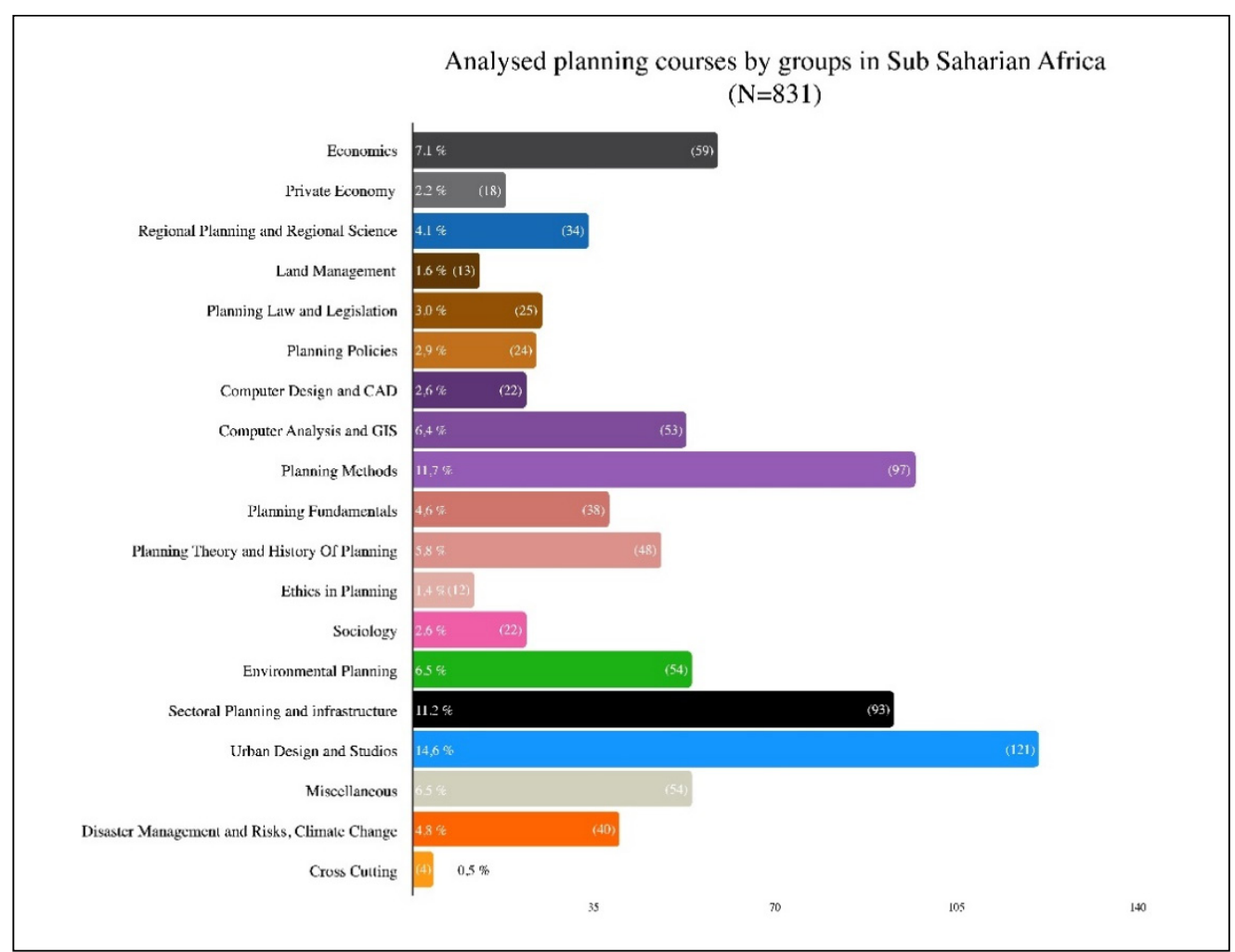

Figure 1. Percentage of urban planning courses offered by groups in sub-Saharan English-speaking Africa (SSA). Graphic: Tim Stober.

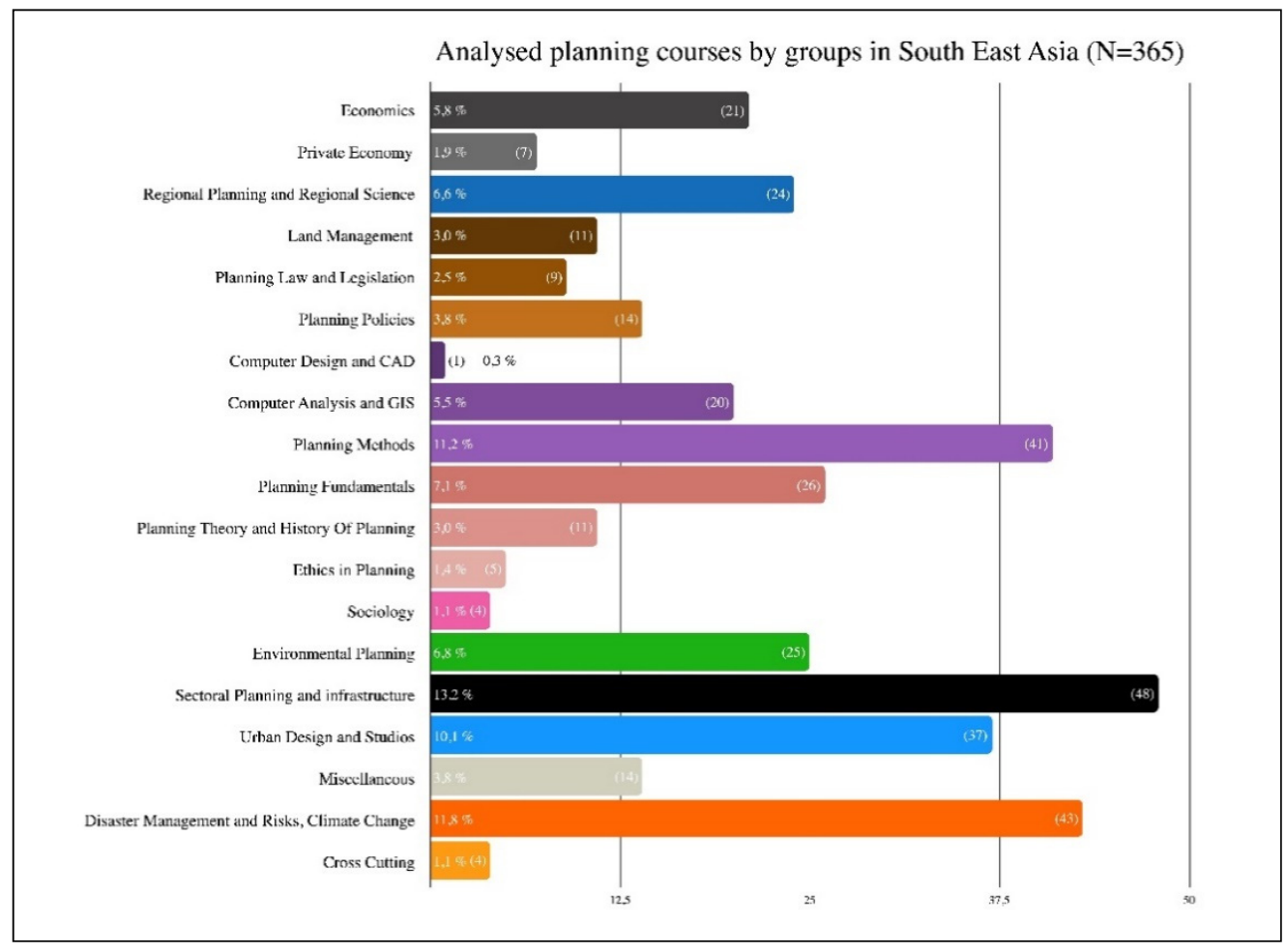

Figure 2. Percentage of urban planning courses offered by groups in South East Asian countries (SEA). Graphic: Tim Stober. 


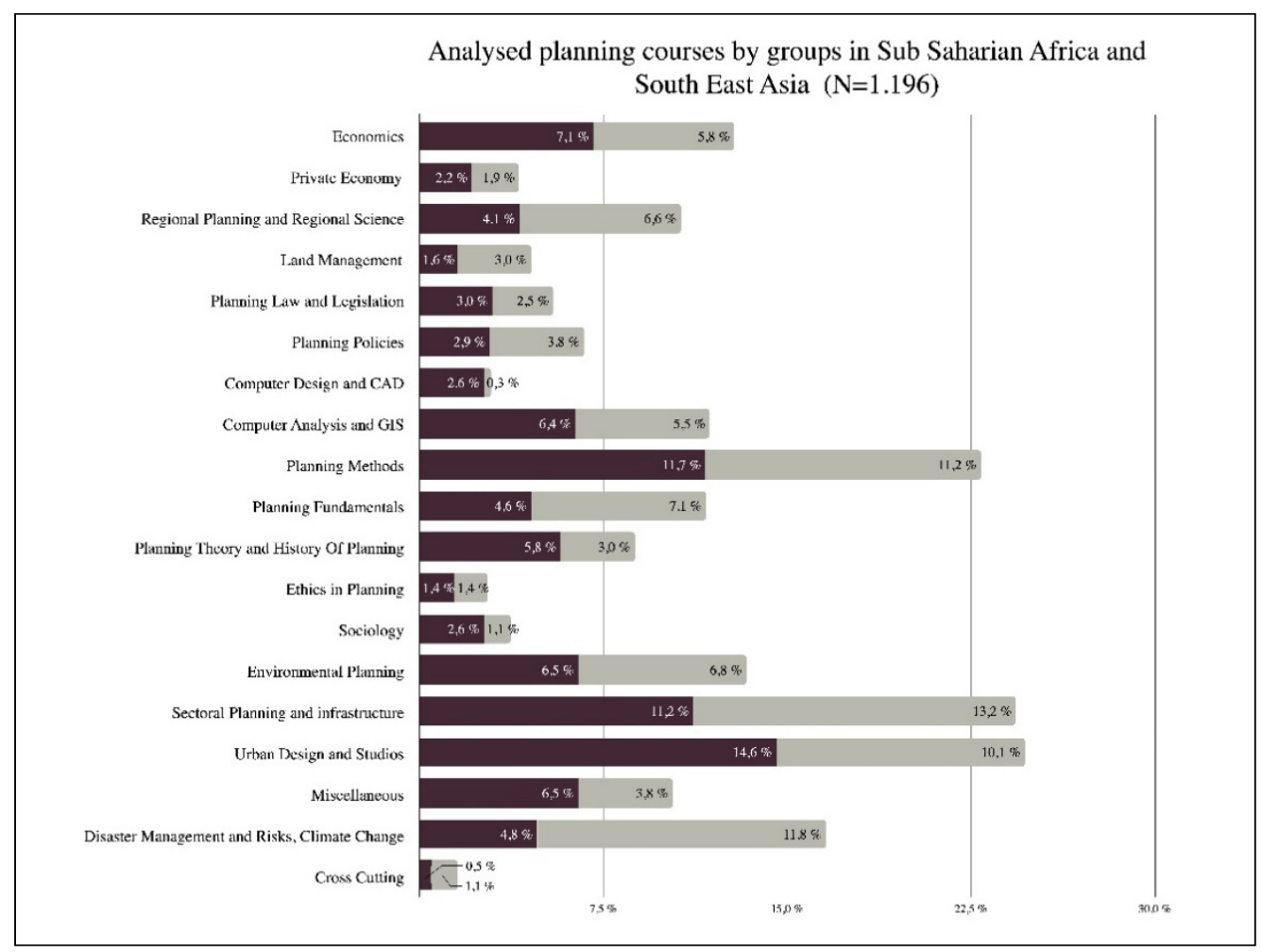

Figure 3. Percentage of the planning courses offered by groups in SSA and SEA. The percentages in each column are calculated for the two regions (SSA, dark blue and SEA, light blue) separately up to $100 \%$ and thus reflect the different total numbers $n$ per region (831 to 365). Graphic: Tim Stober.

In Economics, 59 courses in SSA (7.1\%) and 21 in SEA (5.8\%) were identified. These courses are taught in every country. It is unclear whether these courses also address the earlier discussed problems of poverty and the informal economy.

The second group contains courses related to the private sector economy with 18 courses in SSA and 7 in SEA. These courses are only taught in Botswana, Ghana, Kenya, Namibia and, respectively, one course each in South Africa and Tanzania. In SEA, these courses appear in all three countries. The share of these courses is almost the same $(2.2 \%$ vs. $1.9 \%)$

A third and larger group of courses (34 in SSA and 24 in SEA) deals with Regional Planning and Regional Science. They are taught in most countries and display the importance of regional development. This academic focus can be explained by the still relatively large rural population in Africa and the highly diverse geography in decentralized countries such as Indonesia, the Philippines and Thailand. However, courses specifically on rural development or village planning in SSA are few, which might reflect the (colonial) approach which focused on planning interventions in the urban areas and left the villages rather self-governed, due to limited resources [25]. The direct comparison of the two studied regions shows that the share of the courses in this category differ significantly. In SEA, $6.6 \%$ of the courses fall into the category of regional planning, while only $4.1 \%$ do in sub-Saharan Africa. This finding can be explained by the higher degree of decentralization and geography in the analyzed countries in SEA.

A crucial subject is Land Management, as highlighted in Section 2. Only 13 courses in SSA (1.6\%) and 11 courses in SEA (3.2\%) were identified. In Ghana, Kenya, and Zambia there are no specific courses by name dealing with land management, while, in the other countries, the number is very low. In both regions, the question remains open whether these courses also cover informal land tenure systems, which is a vital topic in this context.

An associated topic is planning law and legislation. A total number of only 25 courses in SSA (3\%) and 9 in SEA $(2.5 \%)$ is available in each country. This is an unexpected 
finding from a European perspective, since students have to be well educated in the legal foundation of planning. The courses cover, most likely, the formal legal system, as seen in the available course descriptions and leave informal arrangements behind.

The next category deals with planning policies. Here, 24 courses in SSA $(2.9 \%)$ and 14 in SEA (3.8\%) are summarized. They are offered in almost all countries and reflect the importance of (national) policies in urban planning.

The next two groups are related to Computer Design and CAD (22 SSA and only 1 SEA) and Computer Analysis and GIS (53 in SSA and 20 in SEA). These courses are offered in almost every program and underline the wide application of the tools. However, unexpectedly, Computer Design and CAD courses are taught only in one out of the 14 courses in SEA. Since the application of the programs is important for urban planners, the content of CAD might be given either in GIS classes or in other courses. Another interpretation could be the existence of Architecture and Urban Design programs at the same university, which splits the disciplines into more design-oriented programs and more analytical spatial planning programs, which do not necessarily need CAD courses.

Under the heading Planning Fundamentals, 38 courses in SSA and 26 in SEA are grouped and provide basic theoretical knowledge for urban planners. This wide group of subjects is available in every country. The share of these courses in SEA with $7.2 \%$ is much higher than in SSA with $4.6 \%$ only. However, this might also be related to the structure of naming the courses.

Similar to the category before, the group Planning Theory and History of Planning is focusing on theoretical knowledge with special emphasis on theories dealing with the planning process and the role of planners. In total, 48 courses in SSA and 11 in SEA are grouped here. In this category, topics of informal planning processes and decision-making processes could be included but are not clearly stated as such. The share in SSA with $5.8 \%$ is higher than in SEA with 3.2\%. This difference can be explained by the different extent of influence from European and US-American planning schools and experts on the SSA curricula development. In European and US-American planning schools, planning theory has been developed and is widely accepted as an essential part of planning education.

12 courses in SSA deal with the important topic of ethics in planning, but are available only in Kenya, Nigeria, South Africa, and Uganda. In SEA, four concerned courses are available in Indonesia, one in Thailand but none in the Philippines. Since ethics in urban planning play an important role, due to the strong legal power of urban planning and the potential risks of a misuse of this legal power in land-use planning, building control and land management, the total number seems to be quite low.

In the Planning Methods category, the focus is on practical tools for planners. In total, 97 courses are taught in all universities in SSA, and 41 in all universities in SEA. The share of the courses is the same in both regions, with $11.7 \%$.

Coming to more specific or sectoral courses, starting with Sociology, only 22 courses in only 12 universities are offered in SSA universities. In Botswana and Tanzania, there are no courses dealing with sociological topics, while in the other countries at least one university is offering the subject. This number is quite low considering the potential of these courses to bridge the gap between imported Northern urban planning theories and urban planning in Southern realities. Interestingly, the number of courses in sociology is even lower in SEA, with a share of only $1 \%$ in comparison to SSA with $2.6 \%$. This finding obviously needs further research to understand the lack of sociology-related courses in SEA.

In Environmental Planning, we found 54 courses in SSA and 25 in SEA. The importance of the environment in planning is reflected by offers at all universities and a similar share (6.5\% in SSA and $6.8 \%$ in SEA). It can be seen as a success story of the demand for environmental courses in urban planning, starting in the 1990s with the Rio Summit on sustainable development.

In sectoral planning and infrastructure, all courses on technical and social infrastructure services (93 in SSA and 48 in SEA) are summarized. The large number reflects the 
importance of technical aspects in urban planning with a share of $11.2 \%$ (SSA) and $13.2 \%$ (SEA), respectively.

The largest group, however, is related to urban planning and urban design (121 in SSA, which is $14.6 \%$, and 37 in SEA which is $10.1 \%$ ), both with practical courses as urban planning studios and theoretical input courses. The large number reflects the core competence of the urban planning profession.

The remaining courses are grouped under miscellaneous (54 SSA and 14 SEA, respectively).

Finally, regarding the group of subjects, this article pays special attention to courses on Climate Change as well as on Disaster Management and Risks. In total, there are 40 courses in SSA ( $4.8 \%$ of all courses) while there are even 43 in SEA, which is $11.8 \%$ of all courses in SEA. This seems to be a satisfyingly high number because we have only 53 urban planning programs analyzed in SSA and 14 in SEA. However, 27 of the 40 courses in SSA are taught alone at Ardhi University in Tanzania with three special (most likely overlapping) master programs on Disaster Management (see Table 2). So, in the remaining 36 programs in SSA, there are only 13 courses offered. In SEA, we can observe the same picture, 31 of the 43 courses are taught in two specialized master programs at AIT in Bangkok only (see Table 2).

Table 2. Programs with courses on Climate Change as well as on Disaster Management and Risks.

Botswana: University of Botswana: BA in Urban \& Regional Planning: Planning and Management for Climate Change

Kenya: Kenyatta University: BA Environmental Planning and Management: Disaster Management, MA Environmental Planning and Management: Planning for Disaster Preparedness and Management

Namibia: Namibia University of Science and Technology: BA of Town and Regional Planning: Critical City Structure and Components, BA of Regional and Rural Development: Disaster Risk Management (elective)

Nigeria: Obafemi Awolowo University: B. Sc. Urban and Regional Planning: Environmental Hazards and Risk Management

Nigeria: Federal University of Technology, Akure: B. Tech. In Urban and Regional Planning: Disaster Risk Management (elective)

South Africa: North-West University: BA of Urban and Regional Planning: Urban Risk Management

Tanzania: Ardhi University: B. Sc. in Urban and Regional Planning: Planning and Management for Climate Change, B. Sc. in Housing and Infrastructure Planning: Planning and Management for Climate Change, B. Sc. in Regional Development: Planning, Planning and Management for Climate Change

Tanzania: Ardhi University: Master of Disaster Risk Management: Introduction to Disaster Risk Management, Principles of Disaster-Time Occupational Health and Safety, Emergency Planning Management, Research Methods in Disaster Risk Management, Disaster Risk Management Project, Disaster Management Settlement Planning, Theories and Management of Risk and Crisis, Case Studies in Disaster Risk Management, Introduction to Disaster Science and Management

Tanzania: Ardhi University: MSc in Disaster Risk Management: Introduction to Disaster Risk Management, Principles of Disaster-Time Occupational Health and Safety, Emergency Planning Management, Research Methods in Disaster Risk Management, Disaster Risk Management Project, Disaster Management Settlement Planning, Disaster Science and Management-Natural Disasters, Disaster Science and Management-Anthropogenic Disasters, Disaster Science and Management Project 
Table 2. Cont.

Tanzania: Ardhi University: MSc in Disaster Risk Management and Engineering: Introduction to Disaster Risk Management, Principles of Disaster-Time Occupational Health and Safety, Emergency Planning Management, Research Methods in Disaster Risk Management, Disaster Risk Management Project, Disaster Science and Management-Natural Disasters, Disaster Science and Management-Anthropogenic Disasters, Disaster-Time Sanitary and Environmental Infrastructure Engineering, Design and Construction of Disaster Resistant Infrastructure and Facilities

Uganda: Makere University: MA in Urban Planning and Design: Planning for Disaster Recovery and Resilience

Indonesia: Institute of Technology Bandung: Undergraduate Program Urban and Regional Planning: Disaster Aspects in Planning

Indonesia: Institut Teknologi National (ITENAS) Bandung: Undergraduate Program Urban and Regional Planning: Disaster Aspects in Planning, Master Program Urban and Regional Planning: Disaster Mitigation Planning, Geo-Spatial Technology in Disaster Management, Planning and Management for Climate Change

Indonesia: Institut Teknologi National (ITENAS) Bandung: Master Program: Urban and Regional Planning: Disaster Mitigation Studio, Community based disaster risk management, Disaster Mitigation Planning, Planning and Management for Climate Change, Information and Geo-Spatial Technology in Disaster Management, Climate Change Adaption and Policy

Thailand: Thammasat University: Master of Urban Environmental Planning and Development Program: Urban Violence and Catastrophe

Thailand: Asian Institute of Technology: Master of Urban Sustainability Planning and Design, Master in Disaster Preparedness, Mitigation and Management, Master in Climate Change and Sustainable Development, Environment and Sustainable Development

Thailand: Asian Institute of Technology: Master of Urban Sustainability Planning and Design, Master in Disaster Preparedness, Mitigation and Management, Master in Climate Change and Sustainable Development, Environment and Sustainable Development

Thailand: Asian Institute of Technology: Master of Urban Sustainability Planning and Design: Urban Resilience Assessment (elective), Climate Compatible and Infrastructure Development (elective)

Thailand: Asian Institute of Technology: Master in Disaster Preparedness, Mitigation and Management: Human Conflicts and Humanitarian Emergency Management, Health and Ecological Risk Management, Disaster Management, Tsunami Science and Preparedness, Energy Technologies for Disaster Warning and Management, Climate Prediction and Early Warning Systems, EIA Framework for Disaster management, Community based disaster risk management, Disaster Management in Urban Environmental Planning, Disaster Management and Humanitarian Disasters, Mitigation of Earthquake Disasters, Floods and Droughts, Remote Sensing and GIS for Disaster Mitigation, Climate Hazards and Early Warning Systems, Managing disasters, Community Based Disaster Risk Reduction and Management-Theory and Practice, Disaster Governance, Policy and Risk Management, Disaster Response and Emergency Management, Mitigation of Earthquake Disasters

Thailand: Asian Institute of Technology: Master in Climate Change and Sustainable Development: Climate Change Impacts and Adaption in Fisheries and Aquaculture, Climate Change, Agriculture and Food-Security, Climate Change Impacts, Vulnerability and Adaptation: Concept, Tools and Practices, Climate Change Seminar, Climate Change Mitigation, Science of Climate Change and Impact, Climate Compatible and Infrastructure Development (elective), Analytical Tools for Climate Change Adaption at local Level, Adaption to Climate Change: Policies and Practices, Selected Topic: Community and Climate Change Adaption, Climate Change Adaption and Disaster Risk, Land Use and Climate Change

Thailand: Asian Institute of Technology: Environment and Sustainable Development: Urban Resilience Assessment (elective)

Let us have a closer look at these programs and courses on Climate Change, as well as on Disaster Management and Risks, which are offered in SSA and SEA per country, university, and program: 
When looking at the Ardhi University, it seems as if the same courses by name reappear in BSc and in MSc programs. This does not reduce the position of Ardhi University at the forefront of courses in Disaster Management in higher academic education, but it reduces, somehow, the total number of courses offered in Africa when the same course name appears in different programs. The Asian Institute of Technology in Bangkok (AIT) plays a similar leading role for the SEA region. It offers three specialized Master programs with detailed courses on typical risks in the region as tsunami, floods and earthquakes but also covers the wider impacts of disasters in courses on food security as well as community-based approaches and disaster management. The wide range of courses obviously reflects the long-term experience with disasters and their consequences in the region.

We have discussed before that courses on Disaster Risk and Disaster Management as well as Climate Change are cross-cutting courses and cannot be seen separately from urban planning studios, infrastructure planning courses, or courses dealing with issues such as informality and poverty. Therefore, the question is, do we have other cross-cutting courses in SSA and SEA? Yes, we do have, in the 53 programs with 1196 courses, just eight courses dealing with cross-cutting issues such as gender, poverty, informality, or vulnerable groups in the course title:

- Gender and Vulnerability Groups Issues in Physical Planning;

- Gender and Housing;

- Gender Issues in Urban Planning;

- Gender and Development Planning;

- Gender and SMEs in the Global Economy;

- Gender Analysis and Health Policy Research;

- Planning for Informality.

All these courses are only taught at Ardhi University in Tanzania, Makere University in Uganda, as well as at Thammasat University and AIT in Thailand. Courses with poverty in the title are not available and there is only one course with the term informality in its title. This finding clearly indicates the lack of cross-cutting subjects in higher urban planning education in favor of the abovementioned sectoral courses. It does not automatically mean, however, that the content of these topics is completely ignored, it can be "hidden" in the course description or highlighted individually by lecturers during class.

\section{Discussion on Integration of Climate Change, Disaster Risk Management and Cross Cutting Topics into Urban Planning Courses}

It has been shown above that cross-cutting phenomena such as climate change impacts and resilient urban development, which are leading to derived consequences, higher risks, and increased vulnerability, especially of informal settlers, are not fully addressed by the current urban planning curricula, respectively; they are taught only in specialized programs. The same applies, also to a large extent, to other cross-cutting topics, such as poverty, informality, or gender.

The general finding is that courses on climate change and disaster management are not an essential part of planning education in the analyzed programs today. Most courses are clustered in few universities-mainly Ardhi University and AIT. For specific courses on cross-cutting issues, such as gender and vulnerable groups, the representation with eight out of 1196 courses is even lower. The same applies to courses with special focus on poverty and informality in the course title with only one listed. So, the cross-cutting topics of gender, informality, and poverty are underrepresented in the curricula (8) and are far fewer than the number of courses on climate change and disaster risks (83) in both regions.

Today, based on the curricula analysis of 1196 courses, it can be assumed that current planning students have insufficient knowledge of climate change impacts and disaster management and thus lack a sound understanding of the consequences of their landuse plans and layouts on cascading effects, higher vulnerability of social groups and induced risks. 
However, does this automatically mean that these topics are not taught? The content could be also part of other courses as well without specifically mentioning the topic in the course title. This leads to the question on whether we actually need specific courses on climate change, disaster management, gender, poverty, and informality in order to integrate these important issues in higher urban planning education. Thus, there is a need to discuss in-depth options for an integration of the topics into the curricula. Generally, there seems to be three options:

Option A: Adding new specialized courses on climate change and disaster management, gender, poverty, and informality into the existing curricula. This option will be the best to ensure the topics are actually taught. However, due to the limited number of credits and teaching hours available for the programs, it automatically means the need to reduce the teaching time for other subjects. Whether existing courses can be removed from the programs depends highly on the programs. Furthermore, the introduction of new courses does not automatically guarantee the integration of new knowledge into the applied urban planning practice, e.g., into the urban planning studios. The cross-cutting courses might also face problems in urban planning studios due to a contradicting pressure on limited resources available, such as land and financial resources. They might be thus "overlooked" by students if not sensitized by studio masters who, according to my personal experience of teaching in Germany, Tanzania, Ghana, Oman, Vietnam, and the Philippines, often focus primarily on urban design aspects or only technical approaches. In addition, the teaching of these cross-cutting topics in separated courses will not automatically support their mainstreaming in the entire urban planning education, since they might be seen as just another separated sectoral subject, both by lecturers and students.

Option B: Establishment of specialized courses on the mentioned cross-cutting issues, but only at Master level in specialized programs, similar to the already established courses at Ardhi University and AIT. This option seems to have advantages since special focused programs can better mainstream the topics in these master programs. However, the specialized master programs will have only a few students in comparison to the large bachelor programs and thus will not train the majority of future urban planners in these topics. Furthermore, such highly specialized master courses might not reflect the demands of the job market if specialists on these topics are not appreciated everywhere (especially on local level) where rather general urban planners are needed for daily planning activities. Students graduating in these specialized master programs might find employment only in sectoral departments of the ministries on the national level or in academia with a rather limited impact on daily urban planning decisions on the local level.

Option C: There will be no new specific courses on climate change and disaster management, gender, poverty, and informality in the bachelor and master programs, but these topics will be integrated with existing courses as a mandatory part of the course description. They could also be highlighted as a learning objective at the program level or at least at the course level. This would require, however, in most cases, a revision of the accreditation to change the learning objective. Nevertheless, it is worth discussing it in each faculty and referring to national environmental policies to achieve this goal. In this way, it should be seen as "not something separate to what we as planners are already doing, but about thinking differently about how we are planning urban areas" [33]. In this case, there is no need to drop other courses as in option A or establish new courses as in option $B$ and the cross-cutting content can appear in different courses and thus support its mainstreaming throughout the programs. For example, informality could be part of land management as informal land tenure, in economics as informal economy, in urban planning courses as informal land uses, and so on. For climate change, basic knowledge can be part of environmental courses, while climate change adaption and mitigation efforts will be an essential part of sectoral infrastructure planning courses. Climate change policies can be integrated in planning policy courses; adaption and mitigation efforts can be integrated in urban design courses and be part of a binding evaluation checklist for students' design works. Basic concepts of disaster management can be part of planning fundamental courses, 
effects of disasters can be integrated in environmental and infrastructure courses and their application be part of the urban planning studios.

The same approach can be easily applied for the topics of poverty, gender, and vulnerable groups. However, this approach requires adequate knowledge of the subjects and their relationship and interdependencies among the professors. The integration in urban planning studios, for example, means that not only urban design, technical requirements and aspects of climate change and disaster management will be evaluated but also the application of the other cross-cutting topics at the same time. Furthermore, contradictory planning goals have to be balanced in urban planning studio work, which is not easy in the rather academic exercise of urban planning studios.

Option $C$ seems to be the most promising approach, since it will ensure the wide coverage of the topics in most subjects and supports its mainstreaming throughout the programs. Nevertheless, a revision of the course description would be required, which is, however, less demanding than a revision of the entire curricula with new courses. The most important aspect seems to be that it depends on the lecturers and urban studio teachers to integrate climate change and other cross-cutting topics into their courses, which are orientated towards design and technical subjects. A challenge for lecturers is to teach topics which are, at the first glance, contradicting each other (e.g., poverty vs. climate change adaptation and mitigation) and/or not easy to cover comprehensively (e.g., land tenure and land use planning vs. informal land rights and informal land use arrangements) when it comes to urban design and legally binding layout plans.

When coming to the question of how to train professors and lecturers in the topics, we face the following question: Do urban planning programs at universities cater mainly for the job market (in the public planning sector) or for academia? Obviously, they cater to the first sector, in many universities, even according to their statutes. Specialized master courses, as in option B, might provide future well-skilled academic trainers and teachers; however, they have limited job opportunities in the public sector or they train too few students to have those specialists for every local governmental unit. One way out can be, to leave the master level in option B behind and focus instead on specialized PhD programs on the topics of climate change and disaster management as well as other cross-cutting topics. Here, we can cater better for the academic demand for future professors and lecturers as well receive high standard research results to be used in classes or for training programs of professionals. Having such PhD programs, we can cover both the demand for trained lecturers as well as mainstream the topics inside universities. It would also support an international exchange of ideas and approaches, e.g., from SEA to SSA and vice versa, since funding for international $\mathrm{PhD}$ candidates is easier to obtain than for international master students. The two existing clusters at Ardhi University and AIT can serve here as an example for more regional centers of excellence to support mainstreaming the topics. This means first train qualified teaching staff and researchers and then integrate their knowledge into existing planning courses, including the urban planning studios.

These focused PhD programs have to be interdisciplinary, cross-cutting, and cover multiple aspects. However, ivory towers of specialized $\mathrm{PhD}$ holders only in, e.g., gender aspects, poverty or informality, need to be avoided, since it would lead to a purely academic approach with limited impact on planning practice. For planners and lecturers already in the job, tailor-made training programs might be the appropriate approach, which can also be offered by the academic institutions. Therefore, specialized PhD programs on climate change, disaster management, and the abovementioned cross-cutting topics can serve as option $D$ before going for option $C$. The need and the scope for such programs depend, obviously, on the specific local academic and professional circumstances and local climate change-related risks.

However, better-trained lecturers, according to option $D$, might still face problems of the current teaching modes, as shown above, consisting mainly of sectoral input lectures and applied urban planning studios when it comes to cross-cutting subjects as climate change, gender, or informality. These topics seem to be better placed in more interactive 
seminars and student-centered learning modes. By doing so, it is easier to cover the wide range and discuss the implications of the topics in class. It is important to encourage a holistic way of thinking. At this stage, the questions of a Southern perspective gain importance again, since new learning approaches have to carefully consider the local teaching environments at universities in SSA and SEA and thus require locally accepted and working approaches. Knowledge transfer from pedagogies into planning faculties can be a suitable approach, as well as teaching-method seminars for the candidates of option $D$.

Another aspect is that, not only are faculties and universities are responsible for curricula adjustments, but there is a need for support from the national government as well. In this case, national policies do not strongly support climate change actions; the future well-trained students might face problems to apply their knowledge and skills in reality.

Further research is needed to cover those universities in SSA and SEA with no information on the courses and program structure online. The research could also be extended as the next step to francophone and lusophone countries in Africa as a comparison in order to identify potential differences. Additionally, the spread of credit points and not only the course titles can be used to better understand the weighting of the topics in the programs.

Obviously, the discussion will have to continue to find a suitable solution for SSA, SEA and other urban planning schools in the Global South, with localized and locally accepted approaches. It is important to discuss and decide on the ground, in each case reflecting the local academic system and the (legal) urban planning system, and to make use of the international exchange of ideas and approaches in order to avoid the problems that occurred during (colonial) history, as described above.

Author Contributions: Conceptualization, W.S.; methodology, W.S., H.S. and T.S.; software, H.S. and T.S.; validation, W.S., H.S. and T.S.; formal analysis, T.S. and H.S.; investigation, W.S.; resources, W.S., H.S. and T.S.; data curation, W.S., H.S. and T.S.; writing-original draft preparation, W.S.; writingreview and editing, W.S., H.S. and T.S.; visualization, T.S.; supervision, W.S.; project administration, W.S.; funding acquisition, W.S. All authors have read and agreed to the published version of the manuscript.

Funding: This research was funded by the Federal Ministry of Education and Research, Germany: Linking disaster risk governance and land-use planning: the case of informal settlements in hazard prone areas in The Philippines (LIRLAP), 2018-2025, grant number 01LE1906A1.

Institutional Review Board Statement: Not applicable.

Informed Consent Statement: Not applicable.

Data Availability Statement: No new data were created or analyzed in this study. Data sharing is not applicable to this article.

Conflicts of Interest: The authors declare no conflict of interest. The funders had no role in the design of the study; in the collection, analyses, or interpretation of data; in the writing of the manuscript, or in the decision to publish the results.

\section{References}

1. Preston-Jones, A. The Importance of Climate Change Education in Urban Planning: A Review of Planning Courses at UK Universities. In Climate Change, Hazards and Adaptation Options, Climate Change Management; Leal Filho, W., Nagy, G., Borga, M., Chávez Muñoz, P., Magnuszewski, A., Eds.; Springer: Cham, Switzerland, 2020.

2. Faling, W. Climate Change and African Cities in Planning Education; Section 1. 'Revitalizing Planning Education in Africa'. 2011. Available online: https:/ / www.africanplanningschools.org.za/images/downloads/curriculum-resources/toolkits/CC_ toolkit_section1.pdf (accessed on 10 November 2020).

3. United Nations. Transforming Our World: The 2030 Agenda for Sustainable Development; Division for Sustainable Development Goals: New York, NY, USA, 2015.

4. United Nations Framework Convention on Climate Change. Adoption of the Paris Agreement. 2015. Available online: https: //unfccc.int/resource/docs/2015/cop21/eng/109r01.pdf (accessed on 10 November 2020).

5. IPCC. Climate Change 2014: Impacts, Adaptation, and Vulnerability: Working Group II Contribution to the Fifth Assessment Report of the Intergovernmental Panel on Climate Change; Chapter 8: Urban Areas; Cambridge University Press: New York, NY, USA, 2014.

6. Viguié, V.; Hallegatte, S. Trade-offs and synergies in urban climate policies. Nat. Clim. Chang. 2012, 2, 334-337. [CrossRef] 
7. Hebbert, M.; Mackillop, F. Urban climatology applied to urban planning: A post-war knowledge circulation failure: Urban climatology and knowledge circulation failure. Int. J. Urban. Reg. Res. 2013, 37, 1542-1558. [CrossRef]

8. Hamin, E.; Marcucci, D. Mainstreaming climate in the classroom: Teaching climate change planning. Plan. Prac. Res. 2013, 28, 470-488. [CrossRef]

9. Hess, D.J.; Collins, B.M. Climate change and higher education: Assessing factors that affect curriculum requirements. J. Clean Prod. 2018, 170, 1451-1458. [CrossRef]

10. Garschagen, M.; Wood, S.; Garard, J.; Ivanova, M.; Luers, A. Too big to ignore: Global risk perception gaps between scientists and business-leaders. Earth's Future 2020, 8. [CrossRef]

11. Morin, V.M.; Ahmad, M.M.; Warnitchai, P. Vulnerability to typhoon hazards in the coastal informal settlements of Metro Manila, the Philippines. Disasters 2016, 40, 693-719. [CrossRef] [PubMed]

12. Greiving, S.; Du, J.; Puntub, W. Managed retreat-International and comparative perspectives. J. Extrem. Events 2018, 5. [CrossRef]

13. Asian Development Bank. Reducing Disaster Risk by Managing Urban. Land Use. Guidance Notes for Planners; Asian Development Bank: Manila, Philippines, 2016.

14. Greiving, S. Disaster response and spatial planning-Key challenges and strategies. In Spatial Planning and Resilience Following Disasters. International and Comparative Perspectives; Greiving, S., Ubaura, M., Tešliar, J., Eds.; Policy Press: Bristol, UK; Chicago, IL, USA, 2016; pp. 1-16.

15. Birkmann, J.; McMillan, J. Spatial Planning \& Climate Change Adaptation. A Guide for Spatial Planners in Thailand; Routledge: New York, NY, USA, 2019.

16. Okpala, D. Regional Overview of the Status of Urban. Planning and Planning Practice in Anglophone (Sub-Saharan) African Countries. Regional study prepared for Revisiting Urban. Planning: Global Report on Human Settlements; UNHABITAT: Nairobi, Kenya, 2009.

17. Pizarro, R. Climate change, peak oil and new curricula in urban planning education. In Green CITYnomics: The Urban War Against Climate Change; Tang, K., Ed.; Greenleaf Publishing: Sheffield, UK, 2009.

18. Phiri, D. Copperbelt University, Zambia Department of Urban and Regional Planning. 2008. Available online: https://www. africanplanningschools.org.za/images/downloads/papers/Copperbelt-University-(Zambia)-AAPS-2008-Conference-Paper. pdf (accessed on 10 November 2020).

19. Frank, A.I. Adapting, Shifting, Defining New Roles: Education for a Maturing Professional Field. In Urban Planning Education Beginnings, Global Movement and Future Prospects; Frank, A.I., Silver, C., Eds.; Springer: Berlin, Germany, 2018; pp. 131-146.

20. Hurlimann, A. Responding to environmental challenges: An initial assessment of higher education curricula needs by Australian planning professionals. Environ. Educ. Res. 2009, 15, 643-659. [CrossRef]

21. Diaw, K.; Nnkya, T.; Watson, V. Planning education in sub-Saharan Africa: Responding to the demands of a changing context. Plan. Pract. Res. 2002, 17, 337-348. [CrossRef]

22. Nnkya, T.; Lupala, J. Ardhi University, Dar Es Salaam, Tanzania. School of Urban. and Regional Planning. 2008. Available online: https:/ / www.africanplanningschools.org.za/images/downloads/papers/Ardhi-University-(Tanzania)-AAPS-2008 -Conference-Paper.pdf (accessed on 10 November 2020).

23. Home, R. Colonial Urban Planning in Anglophone Africa. In Urban Planning in Sub-Saharan Africa; Silva, C., Ed.; Routledge: New York, NY, USA, 2015.

24. Njoh, A.J. French Colonial Urbanism in Africa. In Urban Planning in Sub-Saharan Africa; Silva, C., Ed.; Routledge: New York, NY, USA, 2015.

25. Scholz, W.; Robinson, P.; Dayaram, T. Colonial Planning Concept and Post-colonial Realities: The Influence of British Planning Culture in Tanzania, South Africa and Ghana. In Urban Planning in Sub-Saharan Africa; Silva, C., Ed.; Routledge: New York, NY, USA, 2015.

26. Odendaal, N. Reality check: Planning education in the African urban century. J. Cities 2012, 29, 174-182. [CrossRef]

27. Shoshkes, E. Jaqueline Tyrwhitt and the Internationalization of Planning Education. In Urban Planning Education Beginnings, Global Movement and Future Prospects; Frank, A.I., Silver, C., Eds.; Springer: Berlin, Germany, 2018; pp. 65-80.

28. Setiawan, B. The Roles of Planning Education in the Decentralization and Democratization Era: Lessons from Indonesia. In Urban Planning Education Beginnings, Global Movement and Future Prospects; Frank, A.I., Silver, C., Eds.; Springer: Berlin, Germany, 2018; pp. $65-80$.

29. Asian Development Bank. The Economics of Climate Change in Southeast. Asia: A Regional Review; Asian Development Bank: Mandaluyong City, Metro Manila, Philippines, 2009.

30. Phuc, M.V.; Vinh, T.T. Integrating Strategic Planning Values into Urban Master Planning Process in Vietnam. In Proceedings of the International Scientific Conference Environmental Science for Construction Industry—ESCI 2018, Ho Chi Minh City, Vietnam, 2-5 March 2018. [CrossRef]

31. Watson, V. The Case for a Southern Perspective in Planning Theory. Int. J. E-Plan. Res. 2016, 3, 23-37. [CrossRef]

32. Muigai, K. Education in Urban Environmental Planning: Conceptual and Contextual Aspects. In A Re-Appraisal of the Urban Planning Process; Mosha, A.C., Ed.; UNCHS: Nairobi, Kenya, 1995.

33. Faling, W. Climate Change and African Cities in Planning Education; Section 2. 'Revitalizing Planning Education in Africa'. 2011. Available online: https:/ / www.africanplanningschools.org.za/images/downloads/curriculum-resources/toolkits/CC_ toolkit_section2.pdf (accessed on 10 November 2020). 